\title{
Effects of dietary inclusion of discarded cabbage (Brassica oleracea var. capitata) on the growth performance of South African Dorper lambs
}

\author{
B.D. Nkosi ${ }^{1,3 \#}$, R. Meeske ${ }^{2}$, M.M. Ratsaka ${ }^{1}$, T. Langa $^{1}$, M.D. Motiang ${ }^{1}$ \\ \& I.B. Groenewald ${ }^{3}$ \\ ${ }^{1}$ Division for Animal Nutrition: Animal Production Institute, P/Bag x 2, Irene, 0062, South Africa \\ ${ }^{2}$ Directorate: Animal Sciences, Department of Agriculture Western Cape, Outeniqua Research Farm, P.O. Box 249, \\ George, 6530, South Africa \\ ${ }^{3}$ Centre for Sustainable Agriculture, University of the Free State, P.O. Box 339, Bloemfontein, 9300, South Africa
}

(Received 25 August 2014; Accepted 4 December 2015; First published online 16 February 2016)

Copyright resides with the authors in terms of the Creative Commons Attribution 2.5 South African Licence.

See: http://creativecommons.org/licenses/by/2.5/za

Condition of use: The user may copy, distribute, transmit and adapt the work, but must recognise the authors and the South African Journal of Animal Science.

\begin{abstract}
A study was conducted to determine the effect of dietary inclusion of discarded cabbage (DC) on the intake and growth performance of lambs. Diets containing 0 (control, DC0), $100 \mathrm{~g} \mathrm{DC} / \mathrm{kg}$ (DC100), $150 \mathrm{~g}$ DC/kg (DC150) and $200 \mathrm{~g} \mathrm{DC} / \mathrm{kg}$ (DC200) were fed ad libitum to 36 South African Dorper lambs (22.0 \pm 1.3 $\mathrm{kg}$ live weight). The dry matter intake (DMI) and lamb growth performance was reduced as the level of cabbage in the diet increased. The feed conversion rate of lambs was negatively affected by inclusion of cabbage in the diet. Diets containing cabbage had a lower DM, OM and aNDF digestibility compared with the control. Nitrogen intake and retention was lower in lambs fed diets containing cabbage. Discarded cabbage can be included in finishing diets for lambs but reduced animal performance can be expected.
\end{abstract}

Keywords: By-products, digestibility, feed intake, lambs, nitrogen, supplementation

\# Corresponding author: DNkosi@arc.agric.za

\section{Introduction}

Availability of high-quality feeds is a major constraint for improved livestock productivity under resource-poor livestock production systems in South Africa (Nkosi \& Meeske, 2010). In combination with the unaffordable feed costs in this country, resource-poor farmers are resorting to whatever resource is available to feed their animals. It is therefore important to find affordable alternative feed sources that can be fed to livestock to improve production. Fortunately, this country is endowed with vegetable and fruit by-products that i) derive from processing food for human consumption; ii) are discarded for human food consumption because of poor quality; and iii) are damaged during harvest (Gertenbach \& Dugmore, 2004; Angulo et al., 2012), which can be used for animal feeding. These by-products are important sources of supplementary protein, vitamins and minerals for animals in developing countries (Katongole et al., 2011). It has been reported that ruminants can tolerate dietary incorporation of these by-products to an extent of $50 \%$ since they have the potential to digest fibre effectively compared with non-ruminants (Boucque \& Fiems, 1988). Incorporation of these by-products in the diets of ruminants has been reported to reduce the risk of acidosis, which is associated with high grain diets (Ferreira et al., 2011).

Discarded cabbage (Brassica oleracea var. capitata) is a vegetable by-product that is available in the fresh produce markets of Tshwane and Johannesburg in South Africa and could be considered a potential non-conventional feed resource for ruminants. Several studies (Gupta et al., 1993; Mekasha et al., 2002) have confirmed that cabbage contains 86 - $140 \mathrm{~g}$ dry matter (DM) $/ \mathrm{kg}, 137$ - $280 \mathrm{~g}$ crude protein (CP)/kg DM, 9 - $17 \mathrm{~g}$ ether extract (EE)/kg DM and $186 \mathrm{~g}$ crude fibre (CF) $/ \mathrm{kg} \mathrm{DM}$. In addition, $10.2 \mathrm{MJ}$ metabolizable energy (ME)/kg DM, an 80.4\% in vitro dry matter digestibility (IVDMD) (Mekasha et al., 2002) and 84\% total digestible nutrients (TDN) (NRC, 2007) were reported for cabbage, making it a good source of nutrients for ruminants. However, cabbage is reported to contain S-methyl-L-cysteine sulphoxide and glucosinolates that depress intake by ruminants (Barry et al., 1984; Barry, 2013).

Previous work in South Africa (Rajadevan \& Schramm, 1989) has shown cabbage to be superior to kikuyu when fed to fish, but less work has been done to determine the optimal dietary supplementation of cabbage to ruminants. Although Wadhwa et al. (2006) reported good animal performance when cabbage was fed to goats, the performance of young lambs fed diets supplemented with cabbage might differ from 
that of goats because these small ruminants differ in their grazing behaviour and digestive dynamics (Nicol et al., 1987; Bartolome et al., 1998). In addition, the goats used by Wadhwa et al. (2006) were six years old and weighed $62 \mathrm{~kg}$ live weight, while sheep feedlot operations in South Africa use weaned lambs that range between 22 and $26 \mathrm{~kg}$ live weight. The present study was therefore conducted to determine the effect of inclusion levels of cabbage on the nutrient utilization and growth performance of lambs.

\section{Materials and Methods}

Batches of discarded cabbage (conquistador and star 3301 cultivars, CPS Seedlings cc., Ciarrafarm, Mispah Road, Greytown, South Africa) were collected once a week for a month from Tshwane Fresh Produce Market, South Africa, and brought to the Agricultural Research Council, Animal Production Institute (ARC-API, South Africa). The material was cut to a chopping length of approximately $5 \pm 2.35 \mathrm{~cm}$ (using butcher knives), sun-dried (to achieve at least $150 \mathrm{~g} \mathrm{DM} / \mathrm{kg}$ ) and utilized in the animal feeding trial. After drying, the cabbage was thoroughly mixed and sampled for analyses and four diets with different inclusion levels of cabbage were then formulated (Table 1 ) to provide the minimum CP requirements of lambs (NRC, 2007). The diets contained cabbage (DC) on an as fed basis: 0 (denoted as DC0), $100 \mathrm{~g} \mathrm{DC} / \mathrm{kg}$ (denoted as DC100), $150 \mathrm{~g} \mathrm{DC} / \mathrm{kg}$ (denoted as DC150) and $200 \mathrm{~g} \mathrm{DC} / \mathrm{kg}$ (denoted as DC200). The diets were fed to 36 South African Dorper ram lambs (18 - 24 months old with a live weight of $22.5 \pm 1.32 \mathrm{~kg}$ ). The lambs were housed in individual metabolism crates $(1.2 \mathrm{~m}$ length $\times 0.74 \mathrm{~m}$ width $\times 0.92 \mathrm{~m}$ height) in an insulated wellventilated barn. Nine lambs were randomly allocated to each diet. The amount of feed offered was always $10 \%$ higher than the previous intake to ensure ad libitum intake, and water was freely available. Prior to the start of the trial, lambs were identified with eartags, and treated against internal parasites with Valbazen ${ }^{\circledR}$ (Pfizer South Africa, 85 Bute Lane, Sandton, Gauteng, South Africa), and external parasites using deadline (Bayer PTY Limited, 27 Wrench road, Isando, Gauteng, South Africa). Twenty one (21) days were allowed for adaptation, followed by a 60 days growth and data collection period. Feed samples were collected weekly and analysed for dry matter (DM), organic matter (OM), CP, gross energy (GE), ether extract (EE), amylasetreated neutral detergent fibre (aNDF), acid detergent fibre (ADF) and acid detergent lignin (ADL), while metabolizable energy (ME) was estimated using the equation of Urriola et al. (2014). Lambs were weighed at the start of trial and then at weekly intervals until the end. Feed samples were collected weekly and daily feed refusals per lamb were collected, weighed, mixed thoroughly and sub-sampled before the morning feeding. Dry matter intake (DMI), average daily gain (ADG) and feed conversion ratio (FCR) (kg feed/kg gain) were determined.

A nutrient digestibility study was conducted during the last 10 days of the growth study. It consisted of a three-day adaptation period to faecal bags and a seven-day collection period. Urine was collected in $10 \mathrm{~L}$ buckets, which contained $100 \mathrm{~mL} 10 \%$ sulphuric acid. Samples of faeces and urine were pooled for individual lambs during the collection period and sub-samples were collected for laboratory analyses. Apparent digestion coefficients were calculated from quantitative feed and faecal data collected during the experiment. All animals were treated according to the regulations of the Animal Ethics Committee of the ARC-API (APIEC 12/011).

The DM content for discarded cabbage, diets and faeces was determined by drying the samples at $60^{\circ} \mathrm{C}$, until a constant weight was achieved, following the procedure of AOAC (ID 93.01, 2005). After drying, the samples were ground through a 1-mm screen (Wiley mill, Standard Model 3, Arthur H. Thomas Co., Philadelphia, PA) for chemical analyses: CP (ID 976.05), OM (ID 942.05) and the EE (ID 954.01) were determined according to the procedure of AOAC (2005); the aNDF, ADF and the ADL according to the procedures of Van Soest et al. (1991); aNDF concentration using heat stable a-amylase (Sigma-Aldrich Co. Ltd., Gillingham, UK, no. A-1278) with sodium sulphite and ADF concentration using the Fibretec System equipment (Tecator Ltd., Thornbury, Bristol, UK). Separate samples were used for ADF and aNDF analysis and both included residual ash. The GE content in diets and faeces was determined with a bomb calorimeter (MC-1000 modular calorimeter, Energy Instrumentation, 135 Knoppieslaagte, Centurion, South Africa). The digestible energy (DE) values of the diets were determined by deducting energy in faeces from GE of diets. The ME was determined by deducting energy of urine and energy loss as methane (assuming $8 \%$ of GE is lost as methane) from the DE (McDonald et al., 2010). Analysis of nitrogen (N) in the diets, faeces and urine samples was done according to AOAC (ID 976.05, 2005).

The experiment was designed as a completely randomized blocked design replicated nine times, and data were analysed using the Genstat (2011) statistical programme. Data of the means for the chemical composition, growth performance and nutrient digestibility in lambs were subjected to a one-way analysis of variance (ANOVA). Means of significant effects were compared using Student's t-LSD (least significant difference) at a 5\% significance level (Snedecor \& Cochran, 1980). The data were fitted in the model:

$$
Y i j=\mu+T i+\beta j+\varepsilon i j
$$


where Yij is the individual observations of the ith treatment and the jth replicate, $\mu$ is the general mean, ti is the effect of the ith treatment, $\beta j$ is the effect of the jth replicate and $\varepsilon i j$ is the random variation or experimental error.

Table 1 Dietary ingredients (\%, as fed basis) for experimental diets fed to lambs

\begin{tabular}{|c|c|c|c|c|}
\hline \multirow{2}{*}{ Ingredient (\%) } & \multicolumn{4}{|c|}{ Treatments* } \\
\hline & DCO & DC100 & DC150 & DC200 \\
\hline Maize & 54 & 48 & 45 & 42 \\
\hline Wheat bran & 10 & 8 & 8 & 8 \\
\hline Molasses meal & 10 & 10 & 10 & 10 \\
\hline Soybean oil cake & 5 & 6 & 5 & 5 \\
\hline Ammonium sulphate & 0.5 & 0.5 & 0.5 & 0.5 \\
\hline Limestone & 1.3 & 1.1 & 1.0 & 1.1 \\
\hline Salt & 0.5 & 0.5 & 0.5 & 0.6 \\
\hline Eragrostis curvula hay & 18.5 & 15.7 & 14.8 & 12.5 \\
\hline Discarded cabbage & 0 & 10 & 15 & 20 \\
\hline Premix finisher** & 0.2 & 0.2 & 0.2 & 0.2 \\
\hline
\end{tabular}

\footnotetext{
* Treatments: DC0: control; DC100: $100 \mathrm{~g} \mathrm{DC/kg;} \mathrm{DC150:} 150 \mathrm{~g} \mathrm{DC} / \mathrm{kg}$; DC200: $200 \mathrm{~g} \mathrm{DC} / \mathrm{kg}$ (as fed basis).

**Premix pack of $2 \mathrm{~kg}$ contained: $0.2 \mathrm{~g}$ selenium; $50 \mathrm{~g}$ iron; $0.2 \mathrm{~g}$ cobalt; $50 \mathrm{~g}$ zinc; $32 \mathrm{~g}$ manganese; $8 \mathrm{~g}$ copper; $0.14 \mathrm{~g}$ iodine.
}

\section{Results and Discussions}

The chemical composition of fresh cabbage shows that it is low in DM $(147 \mathrm{~g} \mathrm{DM} / \mathrm{kg})$, but high in CP content (Table 2). The low DM content of the cabbage suggests that it should be incorporated in a diet rather than fed as sole diet ingredient to ruminants because of the risk of poor animal performance (Nkosi \& Meeske, 2010). The cabbage of the present diet was therefore sun-dried and a DM content of $825 \mathrm{~g}$ was achieved. The CP content of cabbage in the present study was $183 \mathrm{~g} \mathrm{CP} / \mathrm{kg}$ DM (Table1), making it a good source of protein for ruminants. Gupta et al. (1993) reported higher levels of CP (280 g CP/kg DM) in cabbage. Differences in protein level might be attributed to source of origin or species/variety of cabbage (Khan \& Atreja, 2005). The nutritive value of the discarded cabbage in this study was consistent with that reported for cabbage by Gupta et al. (1993), Mekasha et al. (2002) and Negesse et al. (2009).

The experimental diets were isonitrogenous and isoenergetic (Table 3 ) and a similar animal growth performance was expected. However, dry matter intake $(\mathrm{DMI})$ was depressed $(P<0.05)$ with increased level of discarded cabbage (Table 4). Patridge et al. (1985) also reported a reduced DMI when cabbage replaced barley in the diet of rabbits. This reduced DMI owing to the cabbage could be attributed to i) increased dietary fibre (aNDF, ADF and ADL) in cabbage containing diets, which might have reduced the palatability and feed intake of the diets; and ii) the presence of S-methyl-L-cysteine sulphoxide and glucosinolates, which are known to depress feed intake in ruminants fed diets containing brassica (Barry et al., 1984; Barry, 2013). According to Duncan \& Milne (1992), adult sheep (45 - $55 \mathrm{~kg}$ live weight) developed a resistance to brassica glucosinolates by degrading allyl cyanide in the rumen. They demonstrated this by using Scottish Blackface wethers that consumed a diet containing $80 \%$ fresh cabbage DM per day. In the present study young growing lambs were used, that are reportedly more sensitive to glucosinolates than adult or older ruminants (Tripathi \& Mishra, 2007). In the absence of a detailed analysis of S-methyl-L-cysteine sulphoxide and glucosinolates in the present study, future research should focus on these factors when cabbage wastes are fed to growing lambs. According to Wadhwa et al. (2006), cabbage leaves have excellent palatability when fed to goats. The ingestive behaviour of goats, however, differs from that of sheep (Nicol et al., 1987; Bartolome et al., 1998). The ADG of lambs fed the diets containing cabbage was lower $(P<0.05)$ compared with lambs fed the control diet (Table 4). This might be attributed to the higher intakes of CP and energy by lambs fed the control diet compared with the other diets, since efficiency of gain is closely related to feed intakes (Haddad \& Husein, 2004). Haddad \& Husain (2004) also reported higher gains in Awassi lambs when their CP intakes were higher than when CP intakes were lower. The inclusion of cabbage in the diet 
reduced the growth performance of lambs. It has been reported that a diet that supplied less than $7 \mathrm{MJ}$ digestible energy (DE)/kg resulted in a reduced rate of gain and feed efficiency (Beauchemin et al., 1995). However, the DE in the experimental diets was above this threshold (Table 4) and lambs gained between 271 and $223 \mathrm{~g} / \mathrm{d}$.

Table 2 Mean ( \pm SD) chemical composition ( $\mathrm{g} / \mathrm{kg}$ DM unless stated otherwise) of discarded cabbage

\begin{tabular}{lc}
\hline Parameter* $^{*}$ & Value (mean \pm SD) \\
\hline Dry matter (fresh) & $147 \pm 0.92$ \\
Dry matter & $825 \pm 0.89$ \\
Organic matter & $832 \pm 1.44$ \\
Crude protein (CP) & $184 \pm 0.65$ \\
ME MJ/kg DM** & $112 \pm 0.13$ \\
Ether extract (EE) & $15 \pm 0.21$ \\
aNDF & $352 \pm 0.81$ \\
Acid detergent fibre & $236 \pm 1.23$ \\
Acid detergent lignin & $55 \pm 0.41$ \\
Calcium & $13 \pm 1.02$ \\
Phosphorus & $3 \pm 0.46$
\end{tabular}

ME, metabolizable energy; aNDF, amylase treated neutral detergent fibre.

*Triplicate analyses on three batches of cabbages at three different sampling times.

** Calculated as: ME $=-261+(1.05 \times \mathrm{GE})-(7.89 \times \mathrm{CP})+(2.47 \times$ aNDF $)-(4.99 \times \mathrm{EE})$ (Urriola et al., 2014).

Table 3 Chemical composition ( $\mathrm{g} / \mathrm{kg} \mathrm{DM}$ ) of the experimental diets containing different levels of discarded cabbage (DC) fed to lambs $(n=9)$

\begin{tabular}{lcccc}
\hline \multirow{2}{*}{ Parameter } & \multicolumn{3}{c}{ Treatments } \\
\cline { 2 - 4 } & DC0 & DC100 & DC150 & DC200 \\
\hline Dry matter & 869 & 871 & 875 & 873 \\
Organic matter & 882 & 884 & 889 & 890 \\
Crude protein (CP) & 148 & 146 & 147 & 149 \\
ME MJ/kg DM* & 11.9 & 12.1 & 12.1 & 12.2 \\
Ether extract (EE) & 52.2 & 54.1 & 53.7 & 56.9 \\
aNDF & 295 & 307 & 312 & 321 \\
Acid detergent fibre & 127 & 136 & 141 & 144 \\
Acid detergent lignin & 49.6 & 56.3 & 58.5 & 54.7 \\
Calcium & 7.4 & 7.9 & 8.1 & 9.2 \\
Phosphorus & 3.7 & 3.7 & 3.7 & 3.8 \\
\hline
\end{tabular}

ME: metabolizable energy; aNDF: amylase treated neutral detergent fibre.

Treatments: DC0: control; DC100: $100 \mathrm{~g} \mathrm{DC} / \mathrm{kg}$; DC150: $150 \mathrm{~g} \mathrm{DC} / \mathrm{kg}$; DC200: $200 \mathrm{~g} \mathrm{DC} / \mathrm{kg}$ (as fed basis).

${ }^{*}$ Calculated as: $\mathrm{ME}=-261+(1.05 \times \mathrm{GE})-(7.89 \times \mathrm{CP})+(2.47 \times$ aNDF $)-(4.99 \times \mathrm{EE})$ (Urriola et al., 2014).

Although lambs in the present study gained $>150 \mathrm{~g} / \mathrm{d}$, the FCR obtained was higher than 5 , which means that more feed was required per $\mathrm{kg}$ of weight gain. Chestworth et al. (1996) reported FCRs that ranged from 5.5 to 6.0 for Omani sheep fed on diets based on Rhodes grass hay and palm fronds, consistent with our study. In addition, Alhomidy et al. (2011) recorded a poorer FCR of 7 in lambs fed 
concentrates that contained discarded dates. In contrast, Haddad \& Husein (2004) recorded FCR of 3.8 in lambs fed a high concentrate diet.

The digestibility of DM, OM, energy, EE and fibre followed a similar pattern to the growth study (Table 4). However, the intake and digestibility of diets in the present study were high and comparable with those reported by Tripathi \& Mishra (2007). One of the key goals of protein nutrition research in ruminants is to optimize the efficiency of utilization of dietary $\mathrm{N}$ to maximize growth (Frutos et al., 2004). The $\mathrm{N}$ retention is considered the most common index of protein nutrition status in ruminants (Owen \& Zinn, 1988). However, the differences in the quantities of $\mathrm{N}$ excretion in faeces and its influences on $\mathrm{N}$ retention reflected the differences in $\mathrm{N}$ intake between the diets (Table 5). The improved digestibility of $\mathrm{N}$ in the DCO diet is an indication that there was increased $\mathrm{N}$ absorption, showing a more efficient $\mathrm{N}$ use compared with cabbage containing diets. A reduced $(P<0.05) \mathrm{N}$ retention occurred in diets that contained cabbage, which indicates

Table 4 Growth performance and apparent nutrient digestibility in lambs $(n=9)$ fed experimental diets containing different levels of discarded cabbage (DC)

\begin{tabular}{|c|c|c|c|c|c|c|}
\hline \multirow{2}{*}{ Parameters } & \multicolumn{4}{|c|}{ Treatments } & \multirow{2}{*}{$P$} & \multirow{2}{*}{ SEM } \\
\hline & DCO & DC100 & DC150 & DC200 & & \\
\hline \multicolumn{7}{|l|}{ Growth performance } \\
\hline IBW kg & 22.8 & 22.2 & 22.2 & 22.0 & 0.680 & 0.128 \\
\hline FBW kg & $39.5^{\mathrm{a}}$ & $37.5^{\mathrm{b}}$ & $35.9^{\mathrm{d}}$ & $36.6^{c}$ & 0.001 & 0.219 \\
\hline DMI g/d & $1600^{\mathrm{a}}$ & $1552^{b}$ & $1470^{\mathrm{C}}$ & $1420^{d}$ & 0.001 & 3.10 \\
\hline ADG $g / d$ & $271^{\mathrm{a}}$ & $256^{\mathrm{b}}$ & $223^{d}$ & $232^{\mathrm{c}}$ & 0.001 & 1.438 \\
\hline FCR kg/kg & $5.9^{c}$ & $6.1^{\mathrm{b}}$ & $6.6^{\mathrm{a}}$ & $6.1^{\mathrm{b}}$ & 0.001 & 0.052 \\
\hline \multicolumn{7}{|l|}{ Digestibility \% } \\
\hline Dry matter & $69^{a}$ & $65^{b}$ & $62^{\mathrm{c}}$ & $64^{\mathrm{bc}}$ & 0.001 & 0.004 \\
\hline Organic matter & $73^{\mathrm{a}}$ & $68^{b}$ & $64^{c}$ & $65^{c}$ & 0.001 & 0.005 \\
\hline $\mathrm{DE} M J / \mathrm{d}$ & $10.2^{\mathrm{a}}$ & $9.7^{\mathrm{b}}$ & $8.8^{\mathrm{c}}$ & $8.4^{\mathrm{d}}$ & 0.001 & 0.046 \\
\hline Ether extract & $64^{\mathrm{a}}$ & $58^{b}$ & $52^{c}$ & $53^{c}$ & 0.001 & 0.003 \\
\hline aNDF & $56^{\mathrm{a}}$ & $49^{b}$ & $47^{c}$ & $47^{c}$ & 0.001 & 0.004 \\
\hline
\end{tabular}

${ }^{a-d}$ Means in the same row with different superscripts differ significantly $(P<0.05)$.

IBW: initial body weight; FBW: final body weight; DMI: dry matter intake; ADG: average daily gain; FCR: feed conversion rate (kg feed/kg weight gain); DE: digestible energy; aNDF: amylase treated neutral detergent fibre.

Treatments: DC0: control; DC100: 100 g DC/kg; DC150: 150 g DC/kg; DC200: 200 g DC/kg (as fed basis).

Table 5 Effects of including different levels of discarded cabbage (DC) in the diet on the nitrogen (N) utilization of lambs $(n=9)$

\begin{tabular}{lccccccc}
\hline \multirow{2}{*}{ Parameter } & \multicolumn{9}{c}{ Treatments } & \multirow{2}{*}{$\boldsymbol{P}$} & \multirow{2}{*}{ SEM } \\
\cline { 2 - 5 } & DC0 & DC100 & DC150 & DC200 & & \\
\hline \multirow{2}{*}{ Nitrogen intake g/d } & $37.9^{\mathrm{a}}$ & $36.3^{\mathrm{b}}$ & $34.6^{\mathrm{c}}$ & $33.8^{\mathrm{d}}$ & & 0.001 & 0.136 \\
Faecal N g/d & $6.5^{\mathrm{b}}$ & $8.8^{\mathrm{a}}$ & $8.3^{\mathrm{a}}$ & $8.5^{\mathrm{a}}$ & & 0.001 & 0.084 \\
Urinary N g/d & $9.9^{\mathrm{b}}$ & $8.4^{\mathrm{b}}$ & $7.6^{\mathrm{c}}$ & $11.8^{\mathrm{a}}$ & & 0.001 & 0.128 \\
Total N excreted g/d & $16.3^{\mathrm{c}}$ & $17.2^{\mathrm{b}}$ & $15.8^{\mathrm{d}}$ & $20.4^{\mathrm{a}}$ & & 0.001 & 0.111 \\
$\mathrm{~N}$ retention g/d & $21.5^{\mathrm{a}}$ & $19.1^{\mathrm{b}}$ & $18.6^{\mathrm{c}}$ & $13.5^{\mathrm{d}}$ & & 0.001 & 0.012 \\
$\mathrm{~N}$ retention as \% of intake & $56.5^{\mathrm{a}}$ & $52.7^{\mathrm{c}}$ & $54.0^{\mathrm{b}}$ & $39.8^{\mathrm{d}}$ & & 0.001 & 0.159 \\
\hline
\end{tabular}

${ }^{\mathrm{a}-\mathrm{c}}$ Means in the same row with different superscripts differ significantly $(P<0.05)$.

Treatments: DC0: control; DC100: 100 g DC/kg; DC150: 150 g DC/kg; DC200: 200 g DC/kg (as fed basis). 
that increasing cabbage in lamb diets has an adverse effect on $\mathrm{N}$ metabolism in the lambs. This is consistent with the findings of Partridge et al. (1985), who reported that reduced $\mathrm{N}$ retention occurred in rabbits fed diets containing higher levels of cabbage. The highest $(P<0.05) \mathrm{N}$ retention $(\mathrm{g} / \mathrm{d})$ was found in the zero cabbage diet compared with the other diets, indicating a more efficient utilization of dietary $\mathrm{N}$ on this diet. The reduced $\mathrm{N}$ retention and increased faecal $\mathrm{N}$ excretion in lambs fed diets containing cabbage could presumably be due to high fibre intake or the presence of both S-methyl-L-cysteine sulphoxide and glucosinolates in the cabbage supplemented diets.

\section{Conclusions}

The study showed that cabbage could be incorporated in the diets of growing lambs. However, increasing the inclusion of cabbage in the diets of growing lambs caused small but progressive depressions in the digestibility of DM and OM, growth performance and $\mathrm{N}$ retention in lambs compared with diet that contained no cabbage. In addition, work is needed to determine to what extent the S-methyl-L-cysteine sulphoxide and glucosinolates in cabbage supplemented diets could cause depression in growing ruminants.

\section{Acknowledgements}

The authors wish to thank Gauteng Department of Agriculture, Conservation and Environment for funding this project. The assistance of L. Maesela (taking care of the experimental animals), and of Cynthia Ngwane (statistical design) is appreciated.

\section{Authors' contributions}

BDN and RM were in charge of project design and writing of the manuscript. BDN, MMR, TL and MDM were in charge of project implementation. All co-authors participated in results, statistics and interpretation of the study.

\section{Conflict of interest declaration}

We wish to confirm that there are no known conflict of interest associated with the publication of this manuscript and there has been no significant financial support for this work that could have influenced its outcome. We also confirm that this manuscript has been read and approved by all authors and that the order of authors listed in the manuscript has been approved by all of us.

\section{References}

Alhomidy, S.N., Basmaeil, S., Al-Owaimer, A.N., El-Waziry, A.M. \& Koohmaraie, M., 2011. Effects of feeding different amounts of discarded dates on growth and efficiency of digestion in sheep. Aust. J. Basic Appl. Sci. 5, 636-640.

Angulo, J., Mahecha, L., Yepes, S.A., Yepes, A.M., Bustamante, G., Jaramillo, H., Valencia, E., Villamil, T. \& Gallo, J., 2012. Quantitative and nutritional characterization of fruit and vegetable waste from marketplace: A potential use as bovine feedstuff? J. Environm. Manage. 95 (Suppl.), S203-S209.

AOAC, 2005. Official Methods of Analysis. 18th ed. Association of Official Analytical Chemists, Eds: Horwitz, W. \& Latimer Jr., G.W., Gaithersburg, Maryland, USA.

Barry, T.N., 2013. The feeding value of forage brassica plants for grazing ruminant livestock. Anim. Feed Sci. Technol. $181,15-25$.

Barry, T.N., Manley, T.R., Millar, K.R. \& Smith, R.H., 1984. The relative feeding value of kale (Brassica oleracea) containing normal and low concentrations of S-methyl-L-cysteine sulphoxide (SMCO). J. Agric. Sci., Camb. 102, 635-643.

Bartolome, J., Franch, J., Plaixats, J. \& Seligman, N.G., 1998. Diet selection by sheep and goats on Mediterranean heath-woodland range. J. Range Manage. 51, 383-391.

Beauchemin, K.A., McClelland, L.A., Jones, S.D.M. \& Kozub, G.C., 1995. Effects of crude protein content, protein degradability and energy concentration of the diet on growth and carcass characteristics of market lambs fed high concentrate diets. Can. J. Anim. Sci. 75, 387-395.

Boucque, C.V. \& Fiems, L.O., 1988. Vegetable by-products of agro-industrial origin. Livest. Prod. Sci. 19, 97-135.

Chestworth, J.M., Byerley, D.J. \& Mahgoub, O., 1996. Evaluation of whole date palm frond as a forage for sheep. Anim. Sci. 62, 664 (Abstr.).

Duncan, A.J. \& Milne, J.A., 1992. Rumen microbial degradation of allyl cyanide as a possible explanation for the tolerance of sheep to brassica-derived glucosinolates. J. Sci. Food Agric. 58, 15-19.

Ferreira, E.M., Pires, A.V., Susin, I., Mendes, C.G., Queiroz, M.A.A., Araujo, R.C., Gentil, R.S. \& Loerch, S.C., 2011. Apparent digestibility, nitrogen balance and ruminal constituents in ram lambs fed high-concentrate diets containing soybean hulls. J. Anim. Sci. 89, 4127-4133.

Frutos, P., Raso, M., Hervás, G., Mantecón, A.R., Pérez, V. \& Giráldez, F.J., 2004. Is there any detrimental effect when a chestnut hydrolyzable tannins extract is included in the diet of finishing lambs? Anim. Res. 56, 127-136.

Genstat for Windows ${ }^{\circledR}, 2011$. The Guide to Genstat R, 14th ed. Ed: Payne, R.W., VSN International Ltd., Oxford, UK., ISBN 1-904375-08-1.

Gertenbach, W.D. \& Dugmore, T.J., 2004. Crop residues for animal feeding. S. Afr. J. Anim. Sci. 5, 49-51.

Gupta, R., Chauhan, T.R. \& Lall, D., 1993. Nutritional potential of vegetable waste products for ruminants. Biores. Technol. 44, 263-265. 
Haddad, S.G. \& Husein, M.Q., 2004. Effect of dietary energy density on growth performance and slaughtering characteristics of fattening Awassi lambs. Livest. Prod. Sci. 87, 171-177.

Katongole, C.B., Sabiiti, E., Bareeba, F. \& Ledin, I., 2011. Utilization of market crop wastes as animal feed in urban and peri-urban livestock production in Uganda. J. Sust. Agric. 35, 329-342.

Khan, M.I. \& Atreja, P.P., 2005. Capturing energy from agro-industrial residues: turning waste into value added products. Proceedings of the Animal Waste Management Symposium, October 5-7, 2005, Raleigh, North Carolina. pp. 710-716.

McDonald, P., Edwards, R.A., Greenhalgh, J.F.D., Morgan, C.A., Sinclair, L.A. \& Wilkinson, R.G., 2010. Evaluation of foods: energy content of foods and energy partition within the animal. In: Animal Nutrition, 7th ed., Chapter 11. pp. 254-280.

Mekasha, Y., Tegegne, A., Yami, A. \& Umunna, N.N., 2002. Evaluation of non-conventional agro-industrial by-products as supplementary feeds for ruminants: in vitro and metabolism study with sheep. Small Rumin. Res. 44, 25-35.

Negesse, T., Makkar, H.P.S. \& Becker, K., 2009. Nutritive value of some non-conventional feed resources of Ethiopia determined by chemical analyses and in vitro gas method. Anim. Feed Sci. Technol. 154, 204-217.

Nicol, A.M., Poppi, D.P., Alam, M.R. \& Collins, H.A., 1987. Dietary differences between goats and sheep. Proc. New Zealand Grassl. Assoc. 48, 199-205.

Nkosi, B.D. \& Meeske, R., 2010. Effects of ensiling a totally mixed potato hash ration with or without a heterofermentative bacterial inoculant on silage fermentation quality, aerobic stability, growth performance and digestibility in lambs. Anim. Feed Sci. Technol. 161, 38-48.

NRC, 2007. Nutrient requirements of small ruminants: Animal Nutrition Series. National Research Council, The National Academy Press, Washington, D.C. pp. 326.

Owen, F.N. \& Zinn, R., 1988. Protein metabolism in ruminant animals. In: The Ruminant Animal Digestive Physiology and Nutrition. Ed: Church, D.C., Waveland Press Inc., Prospects Heights, IL, USA. pp. 227-249.

Partridge, G.G., Allan, S.J. \& Findlay, M., 1985. Studies on the nutritive value of roots, cabbage and grass silage for growing commercial rabbits. Anim. Feed Sci. Technol. 13, 299-311.

Rajadevan, P. \& Schramm, M., 1989. Nutritional value of cabbage and kikuyu grass as food for grass carp, Ctenopharyngodon idella Val. S. Afr. J. Anim. Sci. 19, 67-70.

Snedecor, G.W. \& Cochran, W.G., 1980. Statistical Methods. 7th ed., Iowa State University Press. Ames, Iowa, USA.

Tripathi, M.K. \& Mishra, A.S., 2007. Glucosinolates in animal nutrition: A review. Anim. Feed Sci. Technol. 132, 1-27.

Urriola, P.E., Li, M., Kerr, B.J. \& Schurson, G.C., 2014. Evaluation of prediction equations to estimate gross, digestible and metabolisable energy content of maize dried distillers grains with solubles (DDGS) for swine based on chemical composition. Anim. Feed Sci. Technol. 198, 196-202.

Van Soest, P.J., Robertson, J.B. \& Lewis, B.A., 1991. Methods of dietary fiber, neutral detergent fiber, and non-starch polysaccharides in relation to animal nutrition. J. Dairy Sci. 74, 3583-3597.

Wadhwa, M., Kaushal, S. \& Bakshi, M.P.S., 2006. Nutritive evaluation of vegetable wastes as complete feed for goat bucks. Small Rumin. Res. 64, 279-284. 